\title{
燃料蒸気一空気希薄予混合気中における燃料液滴の自発点火*
}

\author{
津 江 光 洋*1, 石 丸 \\ 亮*2, 中谷辰 爾*1 \\ 岡 井 敬一*3, 森上 \\ 修*4, 河 野 通 方*1
}

\section{Spontaneous Ignition of Fuel Droplets in Lean Premixtures of Fuel Vapor and Air}

\author{
Mitsuhiro TSUE ${ }^{* 5}$, Ryo ISHIMARU, Shinji NAKAYA, \\ Keiichi OKAI, Osamu MORIUE and Michikata KONO \\ ${ }^{* 5}$ Department of Aeronautics and Astronautics, University of Tokyo, \\ 7-3-1 Hongo, Bunkyo-ku, Tokyo, 113-8656 Japan
}

\begin{abstract}
Experiments were carried out on the spontaneous ignition of single fuel droplets in lean premixtures of fuel vapor and air. The n-dodecane droplet was rapidly inserted into high temperature environments and the ignition delay time was obtained from the measurement of $\mathrm{OH}$ emissions. Methane and propane were employed as the fuel of premixtures. The waiting time between the introduction of premixture into the hot furnace and the start of experiment of droplet ignition is defined as the residence time. The calculation of chemical reaction of fuel vapor-air mixtures in high temperature during the residence time was also conducted in order to explore the time history of chemical species concentration. In the case of short residence time where the reaction of premixtures does not proceed so much, the ignition delay time is almost the same as that in the air environment, which indicates that the existence of fuel vapor in ambient environments has little effect on the spontaneous ignition behavior. The ignition delay time becomes larger than that in air in the long time residence time, which is due to the decrease in the oxygen concentration in premixtures.
\end{abstract}

Key Words : Liquid Fuel, Ignition, Chemical Reaction, Droplet, Ignition Delay Time

\section{1. 䅦}

内燃機関の高効率, 低公害化をめざす上で, 燃料 噴霧の点火を制御する試みが盛んに行われている. また，低 N0x 燃焼器として実用化が進められている ガスタービン用の予混合予蒸発燃焼器において, 予 蒸発管内の逆火を防止することは重要な課題である. これらの技術的課題を解決するためには, 液体燃料 の点火機構の詳細を明らかにすることが必要とされ ている.

従来から, 液体燃料の自発点火に関する研究は数 多くなされてきた. 特に懸垂線先端に固定された単 一液滴を対象とした実験は比較的簡便に行うことが でき，解析が容易であるという長所を有するため, 液体燃料性状(1), 雾囲気圧力および温度 ${ }^{(2)}$-(6), 液滴 径(わおよび周囲気体流動 ${ }^{(8)}$ の影響等に関する実験的 および解析的研究が行われている. また, 液滴群に

* 原稿受付 2003 年 8 月 22 日.

*1 正員, 東京大学大学院工学系研究科(®113-8656 東京都文 京区本郷 7-3-1).

*2 東京大学大学院新領域創成科学研究科.

*3 正員, (独) 航空宇宙技術研究所 (画182-8522 調布市深大寺 東町 7-44-1)

*4 正員, 山口大学工学部 (要755-8611 宇部市常盤台 2-16-1).

E-mail : tsuem@mail.ecc.u-tokyo.ac.jp
おける液滴間の相互干渉に関する基礎的知見を得る ため，複数の液滴を直線上に並べた液滴列(9).(10)， あ るいは液滴を 2 次元的に配列した液滴マトリックス (11)を用いた研究が行われている. さらに，低温反応 に由来する冷炎の発生後に熱炎が発生する，いわゆ

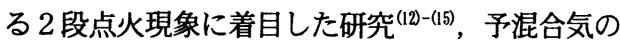
火炎伝播中における液滴の自発点火挙動に関する実 験的研究 ${ }^{(16)}$, および予混合噴霧の点火に関する数値 計算 ${ }^{(1)}$ 等が報告されている.

ディーゼル機関におけるパイロット噴射を用いた 点火制御, あるいは予混合予蒸発燃焼器の蒸発管内 での液滴点火現象等に着目すると, 液滴周囲の雾囲 気にはすでに蒸発した燃料蒸気が存在することが想 定される.このような燃料蒸気が存在する雾囲気中 における液滴の自発点火に関する研究は, Ni i oka らによる数值解析 ${ }^{(18)}$ を除いて報告されておらず，実 験による基礎デー夕の報告例は見受けられない，そ こで本研究では, 雾囲気中に存在する燃料蒸気が液 滴の自発点火挙動に及ぼす影響に関する基礎的知見 を得ることを目的とする. 可燃限界外の燃料蒸気一 空気希薄予混合雾囲気中における単一液滴の自発点 
火遅れ時間を測定するとともに，高温䨌囲気中に滞 留する予混合気の組成变化に関する反応計算を用い て, 予混合気雾囲気条件が液滴の自発点火挙動に及 ぼす影響を考察する.

\section{2. 実踰㯰および方法}

燃焼容器内部に, 高温容器, 液滴生成装置および 液滴移動装置が設置されており,これらは既報(1)で 用いられたものとほぼ同様である. 高温容器は内径 $40 \mathrm{~mm}$, 高さ $50 \mathrm{~mm}$ のステンレス製円筒容器であり, 燃焼容器の上部に固定されている. 高温容器周りに 電気ヒータが巻かれ，その周りはガラス製のブラン ケットで覆われている. 高温容器内部の雾囲気温度 測定にはクロメルアルメル熱電対が用いられ, 温度 コントローラにより所定の雲囲気温度が維持される.

燃焼容器下部に液滴生成装置および液滴移動装置 が設置されている. 液滴生成装置は燃料供給針，お よび供給針を懸垂線先端付近に移動させるロータリ ーソレノイドと液体然料を送り出すシリンジからな る. シリンジはステッピングモータによってピスト ンを上下動させるネジ式機構のものであり,これに より燃料が供給針に送られる. 液体燃料として, 正 ドデカン $\left(\mathrm{n}-\mathrm{C}_{12} \mathrm{H}_{26}\right.$, 沸点 $\left.489.5 \mathrm{~K}\right)$ を用いた. 懸垂 線は直径 $0.125 \mathrm{~mm}$ の石英線である. 作成された液滴 は上方に位置する高温容器加熱の影響を受け, その 温度が上昇する. そこで, クロメルアルメル熱電対 により懸垂された液滴温度を計測し，全実験条件に おいて初期液滴温度が一定 (412K) となるようにし た. 液滴初期直径は $0.6 \mathrm{~mm}$ から $1.2 \mathrm{~mm}$ の間で変化さ せた. 懸垂夜滴は, ステッピングモー夕駆動の往復 スライダクランク機構を有する液滴移動装置により, 高温容器内に瞬時に挿入される. 高温容器内におけ る液滴の自発点火挙動は, CCD カメラにより観察さ れた. また, 自発点火遅れ時間は, 干涉フィルタ

$(308.2 \mathrm{~nm})$ と光電子増倍管を用いた $\mathrm{OH}$ 自発光測定 から求められた.

高温容器に充填される燃料蒸気一空気予混合気は, 混合気タンクを用いて分圧法により作成された. 燃 料，窒素およひ酸素は所定の濃度になるように混合 気に充填され，生成された予混合気は粯汼機により， 均一な状態に保たれる. 本実験では予混合気の反応 性についても考察を行うことを目的とし, 予混合気 用燃料として，メタンおよびプロパンを用いた. な お，予混合雾囲気の酸素濃度を $21 \%$ (体積分率) 一 定とした.この雾囲気条件は, 燃料が空気（酸素 $21 \%$, 窒素 79\%) 中の窒素の一部と置換されたこと
に対応している．また，燃料濃度は予混合気自体の 自発点火を避けるように可燃限界よりも十分低い值 に設定した. 分圧法による濃度決定にはその精度に 限界があるため, 燃料および酸素濃度はガスクロマ トグラフによる測定結果との比較を行った上で決定 された.

予混合雾囲気が高温容器内に導入されると, 化学 反応により混合気組成が変化することが予想される. そこで, 予混合気が高温容器に導入されてから, 液 滴の自発点火実験を行うまでの待ち時間を滞留時間 と定義し，これを実験パラメータとした. 実験手順 は以下の通りである. まず, 燃焼容器全体を真空ポ ンプで真空にした後, 混合気タンクから予混合気を 導入し, 加熱ヒ一夕により高温容器雾囲気を所定の 温度に設定する. その後, 再度予混合気タンクから 予混合気を導入するとともに排気バルブを開け, 高 温容器内部を掃気しながら, 新気を充填する. 新気 充填後直ちに液滴を作成し, 所定の待ち時間経過後 高温容器内に挿入する. 高温容器内雾囲気圧力は大 気圧とし, 霉囲気温度は $873 \mathrm{~K}, 923 \mathrm{~K}$ および $973 \mathrm{~K}$ の 3 条件とした。

\section{3. 実 結 果}

図 1 は, 923K のメタン一空気予混合気中におけ る自発点火遅れ時間を示したものである. 雾囲気中

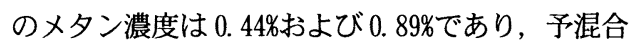
雾囲気の滞留時間は 15 秒である. 自発点火遅れ時 間は高温容器内の所定の位置に液滴が到着した時間 を起点として測定されたものである. 四から, 液滴 初期直径の減少とともに, 自発点火遅れ時間は增加 することがわかる. 従来から報告(7)されているよう

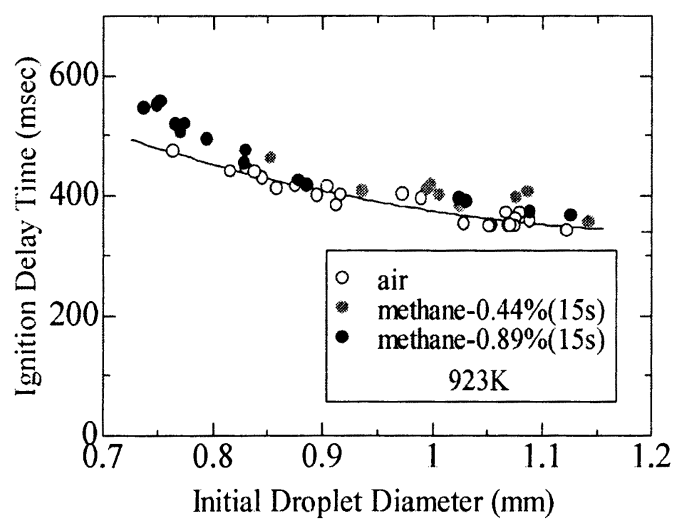

Figure 1 Ignition delay time in methane-air premixtures. (ambient temperature: 923K; residence time: 15s) 


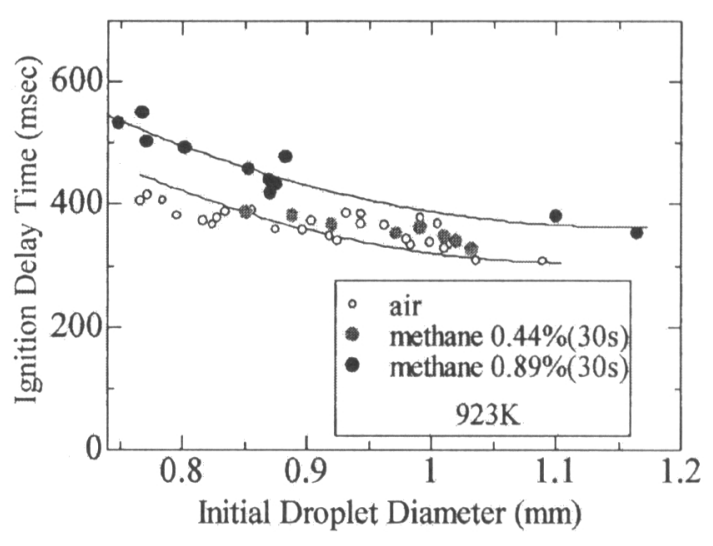

Figure 2 Ignition delay time in methane-air premixtures. (ambient temperature: 923K; residence time: $30 \mathrm{~s}$ )

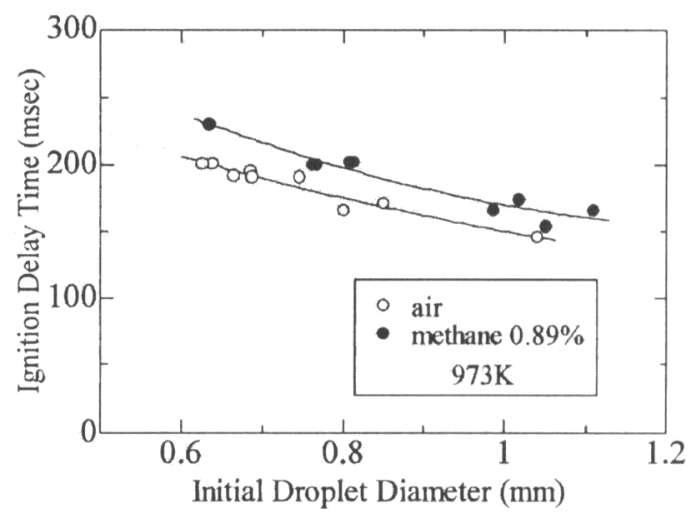

Figure 3 Ignition delay time in methane-air premixtures. (ambient temperature: 973Ki residence time: 15s)

に, これは燃料蒸気質量流束が増大することにより 反応時間が長くなるためである. なお, 正ドデカン のように揮発性が低い燃料の場合, 本実験のような 液滴初期直径の範囲では逆の㑯向, すなわち初期直 径の減少とともに自発点火遅れ時間は減少すること が報告 (13)されているが, 本実験の場合液滴初期温度 が比較的高いために, 燃料蒸気質量流束の増大が顕 著に現れたものと考えられる. また, 雾囲気気体へ のメタンの混入は, いずれの燃料濃度においても自 発点火遅れ時間にほとんど影䅧を及ぼしていないこ とがわかる.この結果は, Niioka らの解析結果 ${ }^{(18)}$ と一致している.

図 2 は, 図 1 と同様な雾囲気気体条件において, 予混合気の滞留時間を 30 秒とした場合の結果であ る. メタン濃度 $0.44 \%$ の場合の自発点火遅れ時間は 空気雾囲気の場合とほぼ同様である一方, メタン濃

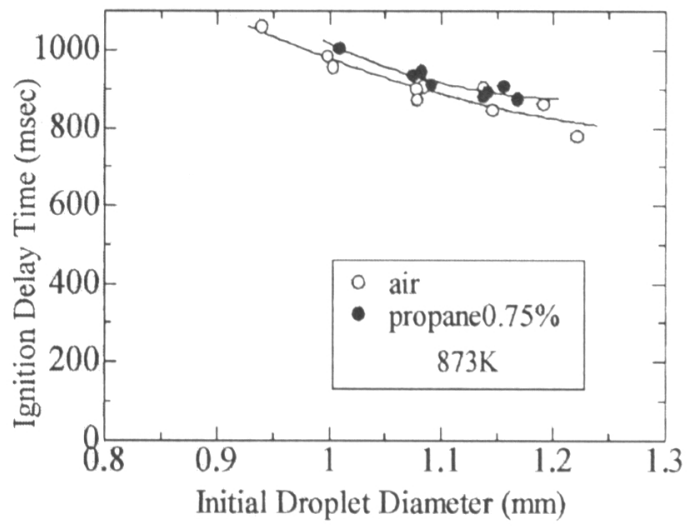

Figure 4 Ignition delay time in propane-air premixtures. (ambient temperature: $873 \mathrm{~K}$; residence time: 15s)

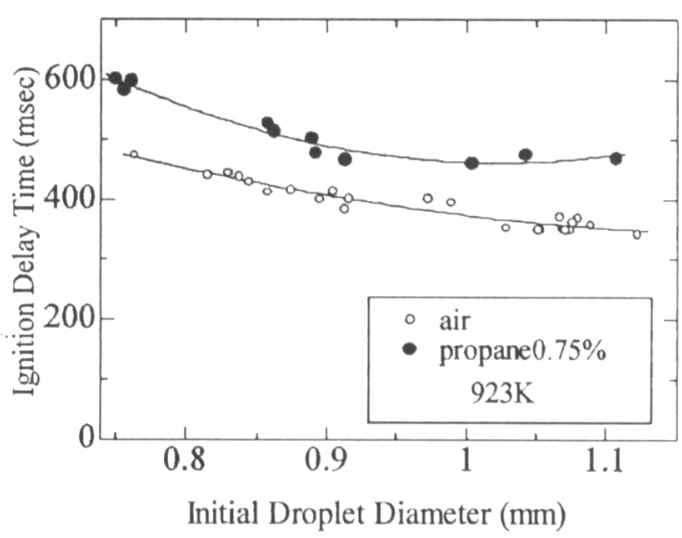

Figure 5 Ignition delay time in propane-air premixtures. (ambient temperature: 923K; resideno time: 15s)

度 $0.89 \%$ における自発点火遅れ時間は空気雾囲気に おけるそれより長くなる傾向を示している.

図 3 は, 雾囲気温度 $973 K$ の場合の結果である. メタン濃度は $0.89 \%$ であり, 滞留時間は 15 秒である。 図より, 自発点火遅れ時間は空気䨌囲気の場合と比 ベて長くなることがわかる.この傾向は, 図1に示 した同様のメタン濃度および滞留時間で雾囲気温度 923K の結果之明らかに異なっている. 図1-3に示 された結果から, 高温容器内に導入されたメタンー 空気予混合気が時間の経過とともに反応し，その組 成の変化が液滴の自発点火挙動に影響を及ぼしてい ることが推察される.このような予混合気挙動に関 する考察は次章で詳紼に唡討する。

図4および5は，空気に $0.75 \%$ のフロパンを混入 させた場合の結果であり, それぞれ雲囲気温度 873K および 923K における自発点火遅れ時間である. 
なお，予混合気の滞留時間はいずれも 15 秒である. 図4から, 雾囲気温度 873K の場合には, プロパン 混入の影響はほとんどなく, 自発点火時間は空気雾 囲気の場合と同様である. 一方，図 5 に示されるよ うに, 雾囲気温度 $923 K$ の場合にはプロパンの混入 は自発点火遅れ時間を増大させることがわかる．ま た図 1 および図 5 の結果を比較すると, 雾囲気温度 および滞留時間が同じ条件においても，予混合気の 燃料性状が異なると, 自発点火遅れ時間に対する影 響に相違が生じていることがわかる.

\section{4. 考察}

化学反応計算を行うことにより, 高温容器内に導 入されたメタン-空気予混合䨌囲気の組成变化を予 測し，それが液滴の自発点火挙動に及ぼす影響につ いて考察を行った. 化学反応モデル(19)は 126 化学種 による 638 個の素反応から構成されている. 計算に は, 陰解法の一つである 5 次の BDF 法 ${ }^{(20)}$ を用いた.

用いた化学反応モデルの妥当性を検証するため, アルゴン希釈の $3.5 \%$ メン一7\%酸素予混合気を用 いた衝撃波管による自発点火実験結果 ${ }^{(21)}$ との比較を 行った. 図6は, 自発点火遅れ時間てに及ぼす雾囲 気温度の影響を示している. 衝撃波管による実験で は, 雾囲気の温度, 圧力等の雾囲気条件に若干不明 確さが存在することの問題等が指摘されているもの の, 化学反応モデルの妥当性をある程度検証するこ とが可能であると思われる. 図から，計算により予 測された点火遅れ時間は実験結果と良い一致を示し ており, 本反応モデルの妥当性を示していると考え られる. なお，この比較計算では， $\mathrm{OH}$ 濃度がピー ク值の $1 / 10$ の值に到達した時点を点火と判定した. メタン-空気予混合気の組成変化を計算するにあ たり, 予混合気の温度は時間の経過によらず初期温 度で一定と仮定した.これは, 高温容器内中央部に 設置された熱電対により計測された予混合雾囲気温 度が滞留期間中ほぼ一定であったという実験結果に 対応させたものである. 本実験で用いられた䨌囲気 は, 可燃限界外の希薄予混合気であり, 反応が比較 的緩やかに起こるために，熱発生と熱損失がほぼ釣 り合った状態となっていたものと推測される.

図 7 および 8 は，それぞれ雾囲気温度 $923 \mathrm{~K}$ およ び $973 \mathrm{~K}$ の $0.89 \%$ メタン-空気予混合気（酸素濃度 21\%）におけるメタンおよび酸素の濃度履歴を示し たものである. 図 7 より, 雲囲気温度 $923 \mathrm{~K}$ では, メタン, 酸素の濃度はいずれも時間とともに緩やか に減少し，85 秒付近でメタン濃度はゼロとなり，

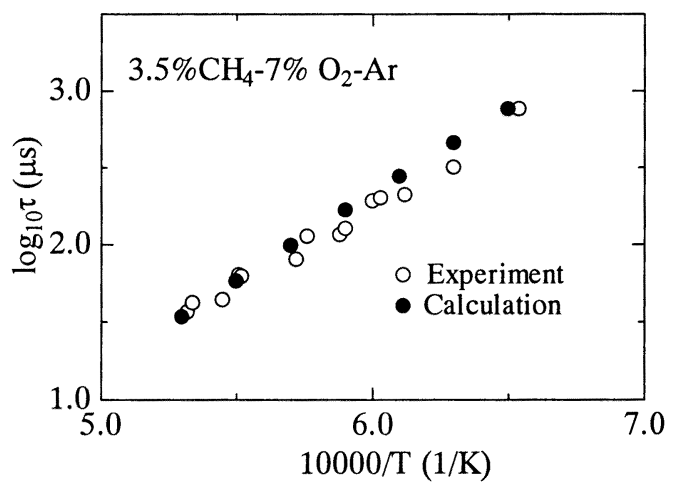

Figure 6 Comparison between experiment and calculation for ignition time.

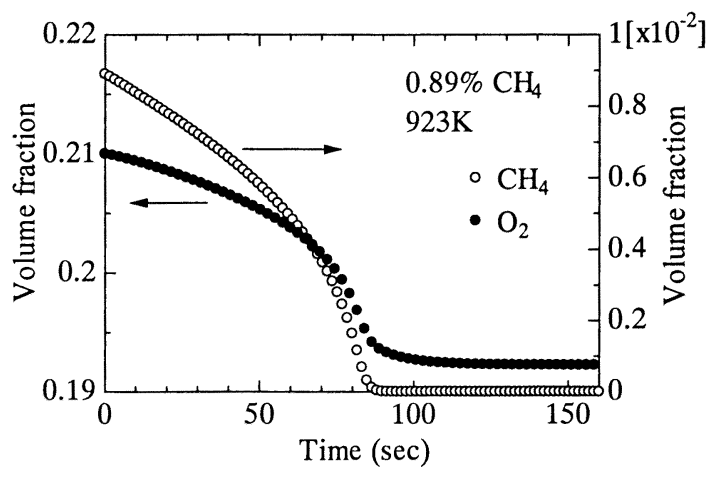

Figure 7 Time histories of methane and oxygen concentrations for ambient temperature of $923 \mathrm{~K}$.

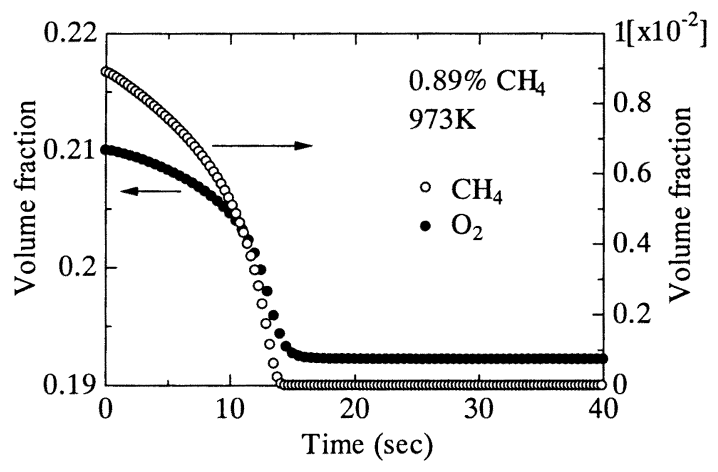

Figure 8 Time histories of methane and oxygen concentrations for ambient temperature of $973 \mathrm{~K}$.

酸素濃度は約 $19 \%$ となっている. 一方, 図 8 に示す ように雾囲気温度 $973 K$ では, 約 15 秒付近でメタン 濃度はゼロとなっている，その時間以降の酸素濃度 は雾囲気温度 $923 K$ の場合とほぼ同様である.これ 
らの計算結果から, 雾囲気温度 $923 \mathrm{~K}$ で滞留時間 15 秒の場合, 予混合気の反応はほとんど進行しておら ず，図 1 に示すように自発点火遅れ時間は空気の場 合と同様であることから, 雾囲気中のメタンの存在 は液滴の自発点火に影響を及ぼしていないと考えら れる.一方図 3 のように, 雾囲気温度 $973 K$ で滞留 時間 15 秒において自発点火遅れ時間が空気雾囲気 の場合に比べて増大した要因は, 予混合気の反応に より酸素が消費されたことによるものと推察される. また, 䨌囲気温度 $923 \mathrm{~K}$ で滞留時間 30 秒の場合, 図 2 のように, メタン $0.89 \%$ における自発点火遅れ時 間は空気雾囲気の場合に対して増大する傾向を示し ている.このことは, 実験では滞留時間 30 秒の時 点で予混合気の反応がかなり進行し, 雾囲気の酸素 濃度が減少していることを示唆している. なお, メ タン $0.89 \%$ にいて，滞留時間を 30 秒以上とした場 合の自発点火遅れ時間は滞留時間 30 秒のそれと同 様であった. このことからも, 滞留時間 30 秒の時 点で予混合気の反応はほぼ終了していると推察され る. 一方, 図 7 の計算結果では, 滞留時間 30 秒の 時点で予混合気の反応はあまり進行しておらず, 酸 素濃度の減少はほとんど見られない。このように予 混合気の反応挙動について実験と計算で相違が見ら れた原因として, 実験では高温容器内部の温度が均 一ではなく, 例えば加熱ヒ一夕近傍では高温領域が 存在し，そのような領域で反応が早く進行すること が考えられる. また，用いた反応モデルの精度等も 考虑する必要があると思われる.

予混合気用燃料としてプロパンを用いた場合，従 来から報告(21)されているようにプロパンはメタンに 比べて反応性が高いため, プロパンが消費され反応 が終了するまでの時間が短くなるものと予測され， これは図 4 および 5 の結果に対応するものである.

図 9 は, 雲囲気温度 $973 \mathrm{~K}$ の場合について, 空気 雾囲気中, メタン濃度 $0.89 \%$ で滞留時間 15 秒の雾囲 気中およびその雾囲気に残留する酸素濃度と同様の 酸素濃度を持つ窒素一酸素混合気中における自発点 火遅れ時間を示している. 計算結果におけるメ夕 ン-空気予混合気の残留酸素濃度は $19.20 \%$ あった が，分圧法による精度の問題により，作成された混 合気の酸素濃度はガスクロマトグラフ計測の結果 18. 83\%であった.

メタン濃度 $0.89 \%$ の場合自発点火遅れ時間は空気 の場合に比べて，約 20\%強の増大を示しているのに 対し, 酸素濃度 18. 83\%の場合は約 50\%の増大を示し

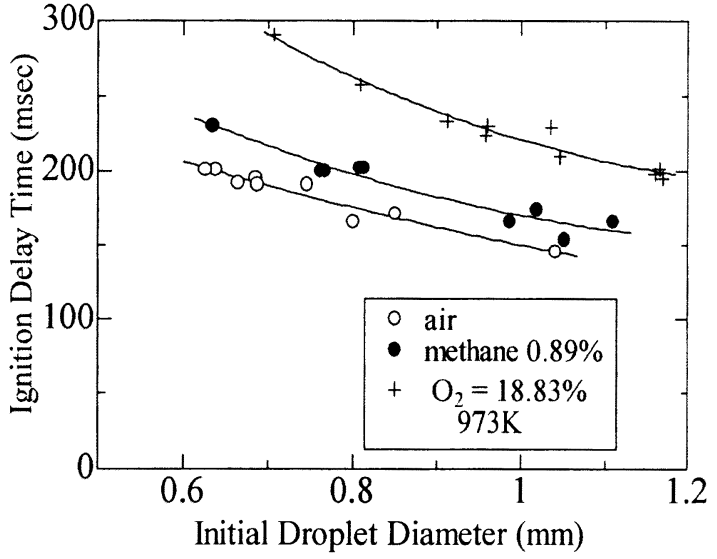

Figure 9 Ignition delay time for air, methane-air premixture and reduced oxygen environments.

ている. 酸素濃度に約 $0.4 \%$ 相違があるため, 両 者の直接的な比較はできないが, 図 9 の結果から, メタン濃度 $0.89 \%$ 場合の自発点火遅れ時間の增大 は, 反応により減少した酸素濃度の影響に比べて小 さいように思われる. このことは, メタン一空気予 混合気の場合, 酸素濃度の減少が自発点火遅れ時間 を増大させる一方, 自発点火遅れ時間を減少させる, すなわち自発点火を促進ざせる要因が存在する可能 性を示唆している. 自発点火過程に影響を及ぼす要 因として，組成变化に伴う比熱等の雾囲気気体の熱 物性值の変化, 反応により生成された活性化学種の 存在等が考えられる.ここでは一例として，活性化 学種の存在について考察する. 雰囲気温度 $973 \mathrm{~K}$ の 場合, 予混合気の反応終了後に約 $1 \times 10^{-5 \%}$ の $0 \mathrm{H}$ が存 在すると計算により予測されている. 上述と同様の 計算手法を用いて, 当量比 1 のエチレン-空気予混 合気について，1810-5\%の $0 \mathrm{H}$ が自発点火遅れ時間に 及ぼす影響を予測した結果, 初期雾囲気中に $\mathrm{OH}$ が 存在しない場合の自発点火遅れ時間が $285 \mathrm{~ms}$ に対し, 上記濃度の $0 \mathrm{H}$ が存在する場合には $180 \mathrm{~ms}$ となり， 自発点火遅れ時間が約 $35 \%$ 短縮することが確認され た.また，酸素濃度 $0.4 \%$ の相違による自発点火遅 れ時間の変化は非常に小さいという結果が得られた. 対象とした燃料が異なるうえに，予混合気の自発点 火挙動を用いて本実験結果を議論することは直接的 な根拠を与えるものではないが，液滴の自発点火現 象は液滴周囲に形成された混合気が自発点火すると 考えれば，いわゆる化学反応の遅れ時間に雾囲気中 に存在する活性化学種がある程度影響を及ぼす可能 性を有すると考えることができる。 
しかしながら, 本実験では燃焼容器下部の低温部 に存在している予混合気が高温容器へ流入し, 酸素 を供給する可能性も否定できないこと等, 実験条件 設定に不明確な点も残されている. したがって, 上 述の自発点火促進効果の詳細な議論を行うためには, 計算による残留酸素濃度の推定のみならず, 計測に よる液滴自発点火実験直前の雾囲気酸素濃度を正確 に把握することが必要であると考えられる.

\section{5. 桔 詥}

燃料蒸気 - 空気予混合気中における燃料液滴の自 発点火挙動に関する実験を行い, 自発点火遅れ時間 を測定するとともに, 高温雲囲気での予混合気の組 成変化に関する化学反応計算結果を用いて, 液滴の 自発点火挙動に及ぼす䨌囲気状態の影響を考察した. その結果, 予混合雾囲気の反応がほとんど進行して いない場合, 䨌囲気中のメタンあるいはプロパンの 存在は, 液滴の自発点火過程に影響を及ぼさないこ とが確認された. 一方, 予混合気が高温需囲気中で 反応した場合には, 空気雾囲気の場合と比較して自 発点火遅れ時間が増大する傾向を示した. これは反 応により酸素が消費され, 雾囲気酸素濃度が減少し たためであると考えられる. しかしながら, 計算に より予測された残留濃度と同様の酸素濃度を有する 空素一酸素混合気中における自発点火遅れ時間の実 測值との比較から, 実験で得られた自発点火遅れ時 間の増大は, 酸素濃度減少の影響に比べて小さいこ とが示唆された.このことは, 燃料一空気予混合雾 囲気の場合には酸素濃度減少による点火抑制の効果 に加えて, 点火を促進させる要因が存在する可能性 を示しているが, これを明確にするためには, 高温 雲囲気中における予混合気の挙動をさらに詳細に把 握する必要がある.

\section{謝辞}

本研究は, 財団法人石油活性化センター $(\mathrm{PEC})$ が 新エネルギー産業技術総合開発機構 (NEDO)から受託 した石油精製污染物質低減等技術開発の一睘として 行われたものである. 実験を行うにあたり, 本学学 部学生（当時）の西中村健一君に多大なるご協力を 頂いた. また, 実験装置に関して, 日本大学生産工 学部助教授野村浩司先生から有益なご助言を頂いた. 記して謝意を表する.

参考文献

（1）森上他，5名, 揮発性の異なる正アルカン液
滴の自発点火, 日本航空宇宙学会論文集, 51-592，pp. 215-219，(2003).

（2）角田他，2名, 高温高圧の気体中における燃 料液滴の着火遅れに関する研究, 機論, 41348, pp. 2475-2485, (1975).

(3) Tsukamoto, T. et al., Ignition Simulation of a Fuel Droplet in High-Pressure High Temperature Atmosphere, Trans. Japan Soc. Aero. Space Sci., 35110, pp. 165-176.

(4) Kadota, T, et al., Autoignition and Combustion of a Fuel Droplet in Supercritical Gaseous Environments under Microgravity, Proc. Comb. Inst. 27, pp. 25952601,(1998).

(5) Segawa, D., et al., Effects of Ambient Pressure on Autoignition of a Fuel Droplet in Supercritical and Microgravity Environment, Proc. Comb. Inst, 28, pp. 1063-1069, (2000).

(6) Shaygan, N., et al., Droplet Ignition and Combustion Including Liquid-Phase Heating, Comb. Flame, 102, pp. 1-10,(1995).

(7) Nakanishi, R. et al., Ignition Experiment of a Fuel Droplet in High-Pressure High-Temperature Ambient, Proc. Comb. Inst., 25, pp. 447-453, (1994).

(8) Huang, L-U,, et al., Droplet Ignition in a HighTemperature Convective Environment, Comb. Flame, 109, pp. 145-162, (1997).

(9) Niioka, T, et al, Ignition Experiment on Droplet Array in Normal and Microgravity Environments, IUTAM Symp. on Mech. And Comb. of Droplets and Arrays, pp. 367-377, (1994).

(10) Goto, M, et al., Numerical Analysis of Ignition of Fuel Droplet Array in Hot Stagnant Air, Proc. Comb. Inst., 27, pp. 1959-1966,(1988).

（11）門脇, 他 4 名, 微小重力場における液滴マト リックスの着火実験, 日本マイクログラビテ イ応用学会誌, 14-1, pp. 17-24, (1997).

(12) Tanabe, M., et al., Effects of Natural Convection on Two Stage Ignition of an n-Dodecane Droplet, Proc. Comb. Inst., 25, pp. 455-462, (1994).

(13) Tanabe, M., et al., Spontaneous Ignition of Liquid Droplets from a View of Non-Homogeneous Mixture Formation and Chemical reactions, Proc. Comb. Inst., 26, pp. 1637-1643, (1996).

(14) Moriue, O., Effect of Dilution by Aromatic Hydrocarbons on Staged Ignition Behavior of n-Decane Droplets, Proc. Comb. Inst, 28, pp. 969-975,, (2000). 
(15) Yang, J.-R. and Wong, S.-C., On the Suppression of Negative Temperature Coefficient (NTC) in Autoignition of n-Heptane Droplets, Comb. Flame, 132, pp. 475-491, (2003).

(16) Segawa, D., et al., Ignition of Binary Mixture Droplets by a Propagating laminar Flame, Proc. Comb. Inst., 28, pp. 961-968, (2000).

(17) Cano Wolff, M., et al., The Influence of Evaporation on the Autoignition-Delay of n-Heptane Air Mixtures under gas Turbine Conditions, Proc. Comb. Inst., 27, pp. 2025-2031,(1988).

(18) Niioka, T, et al, A Numerical Approach to Fuel
Droplet Ignition, Technical Report of National Aerospace Laboratory TR-628T, (1980).

(19) Koert, D., et al., Chemical Kinetic Modeling of High Pressure Propane Oxidation and Comparison to Experimental Results, Proc. Comb. Inst., 26, pp. 633$640,(1996)$.

(20) Gear, C. W., Numerical Initial Value Problem in Ordinary Differential Equations, Engelwood Cliffis, N. J, Princeton Hall, (1971).

(21) Frenklach M. and Bornside, D. E., Shock-Initiated Ignition in Methane-Propane Mixtures, Comb. Flame, 56, pp. 1-27,(1984). 